\title{
REPORT ON INSPECTION REGARDING SMALL BUSINESS CONTRACTING STATISTICS REPORTING AND PRESENTATION
}

APRIL 1998

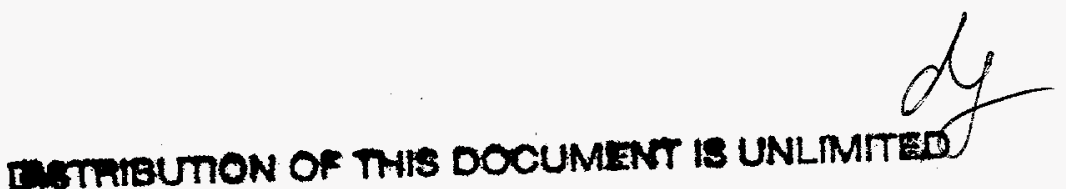

MASTER 


\section{DISCLAIMER}

Portions of this document may be illegible electronic image products. Images are produced from the best available original document. 


\author{
REPORT ON \\ INSPECTION REGARDING \\ SMALL BUSINESS CONTRACTING STATISTICS \\ REPORTING AND PRESENTATION
}

\title{
TABLE OF CONTENTS
}

Page

I. INTRODUCTION AND PURPOSE ............................................. 1

II. SCOPE AND METHODOLOGY …......................................... 2

III. SUMMARY RESULTS OF INSPECTION ................................. 2

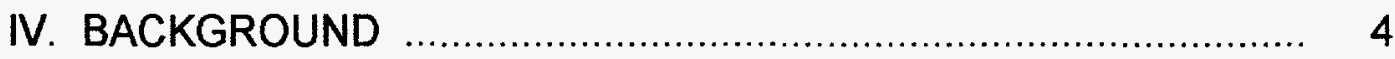

V. RESULTS OF INSPECTION …...................................... 5

A. Annual Report to Congress on the Small Business Program

5

B. FY 1995 Performance Agreement with the President ......... 8

C. Small Business Statistics in Visual Aids Prepared for the Former Secretary

VI. RECOMMENDATIONS

20

\section{APPENDICES}

APPENDIX A - Definitions of Important Terms

APPENDIX B - Development of Small Business Prime Contracting Goal for FY 1995 Performance Agreement 


\title{
U.S. DEPARTMENT OF ENERGY \\ OFFICE OF INSPECTOR GENERAL \\ OFFICE OF INSPECTIONS
}

\author{
REPORT ON \\ INSPECTION REGARDING \\ SMALL BUSINESS CONTRACTING STATISTICS \\ REPORTING AND PRESENTATION
}

\section{INTRODUCTION AND PURPOSE}

On September 11, 1995, the Office of Inspections, Office of Inspector General (OIG), Department of Energy (DOE), received an allegation regarding the accuracy of the Department's small business contracting statistics in the Secretary of Energy's Fiscal Year (FY) 1995 Performance Agreement with the President, entitled: "PERFORMANCE AGREEMENT BETWEEN THE PRESIDENT OF THE UNITED STATES WILLIAM JEFFERSON CLINTON AND THE SECRETARY OF ENERGY HAZEL R. O'LEARY." It was alleged that the FY 1995 Performance Agreement incorrectly communicated that the Department intended to increase small business contracting from 25 percent in FY 1994 to more than 34 percent in FY 1995. We subsequently received additional allegations that the Office of Economic Impact and Diversity (ED) had not issued a required annual report to Congress on the Department's small business program since 1992 as required by the Department of Energy Act of 1978--Civilian Applications, as amended by Public Law 96-470, and may have provided incorrect information for use in Secretarial presentations on the Department's small business program.

On October 13,1995, we referred the above allegations to the Director, ED, and the Acting Assistant Secretary for Policy and International Affairs for appropriate action and response to us. On November 14, 1995, we received a response from the Acting Assistant Secretary for Policy and International Affairs stating that ED should be asked to address the merits of our concerns. We subsequently contacted ED on several occasions to determine the status of their response to our referral. We also provided ED officials with additional copies of our referral letter at their request. However, more than a year after we referred the allegations to ED, we had not received a response from ED regarding the allegations. Since efforts to resolve these issues through the management referral process were unsuccessful, we notified the Director, ED, on February 13,1997, that we would conduct a review of issues regarding the allegations as part of our ongoing inspection of the Department's small business contracting goals.

During this inspection, we sought to determine if the Office of Economic Impact and Diversity: 
1. Issued the annual "Report to Congress on the Small Business Program" for FY 1993, FY 1994, and FY 1995, as required by the Department of Energy Act of 1978--Civilian Applications, as amended by Public Law 96-470, and

2. Notified the Office of the Assistant Secretary for Policy and International Affairs that the Department's small business prime contract goal in the FY 1995 Performance Agreement with the President needed to be revised.

We also sought to determine if:

3. Visual aids prepared for Secretarial presentations contained incorrect information regarding the Department's small business program.

\section{SCOPE AND METHODOLOGY}

In conducting this inspection, we interviewed DOE Headquarters managers and staff personnel in the Office of Economic Impact and Diversity, the Office of the Assistant Secretary for Policy and International Affairs; the Office of the Assistant Secretary for Human Resources and Administration; and the Office of the Assistant Secretary for Congressional, Public, and Intergovernmental Affairs. We also reviewed material related to the development and reporting of small business contracting statistics, including files and copies of presentations given by Secretary Hazel R. O'Leary (hereafter, Secretary O'Leary will be referred to as the "former Secretary").

This inspection was conducted in accordance with the Quality Standards for Inspections issued by the President's Council on Integrity and Efficiency.

\section{SUMMARY RESULTS OF INSPECTION}

The Office of Inspector General received allegations regarding the development and reporting of the Department's small business contracting statistics. Specifically, it was alleged that ED did not issue a required annual report to Congress on the Department's small business program since 1992. It was also alleged that the Department's FY 1995 Performance Agreement with the President incorrectly communicated that the Department intended to increase small business contracting from 25 percent in FY 1994 to more than 34 percent in FY 1995. According to the allegation, although the Department's FY 1995 goal appeared to be an increase over FY 1994, it was actually less than the FY 1994 goal when computed on a comparable basis. Further, it was alleged that ED officials may have provided incorrect information for use in Secretarial presentations on the Department's small business program. 


\section{Annual Report to Congress on the Small Business Program}

We found that the Department was not in compliance with the requirement of the Department of Energy Act of 1978--Civilian Applications, as amended by Public Law 96-470, to provide an annual report within the required time period to Congress on the Department's small business program.

The Department's annual report for FY 1993 was not submitted to Congress until August 1995. At the time of our inspection, however, annual reports for FY 1994 and FY 1995 had not been submitted to Congress, nor, according to ED officials, was the Secretary notified by an Information Memorandum that the reports had not been submitted, as required by Office of Executive Secretariat (ES) guidance.

\section{FY 1995 Performance Agreement with the President}

We found that, although the Department's FY 1995 small business contracting goal had been revised to 18.4 percent and resubmitted to the Small Business Administration (SBA), ED officials did not attempt to change the FY 1995 small business contracting goal ("more than 34 percent") in the FY 1995 Performance Agreement with the President.

The number for the small business contracting goal submitted by the Department to SBA for FY 1995 was 34.5 percent. The Director, ED, said that the number submitted to SBA was also included in the Department's FY 1995 Performance Agreement submitted to the President. In the FY 1995 Performance Agreement, the former Secretary committed the Department to "IMPROVING ACCESS FOR SMALL BUSINESSES." According to the Performance Agreement, success would be measured by increasing small business contracting from 25 percent in FY 1994 to more than 34 percent by the end of FY 1995. About the time that the President signed the Department's FY 1995 Performance Agreement, the Department was notified by SBA that the numbers for the Department's FY 1994 small business contracting achievements and FY 1995 small business contracting goals would have to be revised. According to SBA, unlike previous years, the Department's small business contracting numbers for FY 1994 achievements and FY 1995 goals did not include Management and Operating (M\&O) contractor "salaries and expenses." Although the Department subsequently revised the number for the FY 1995 small business contracting goal to 18.4 percent and submitted the revised number to SBA, ED officials did not attempt to change the FY 1995 small business contracting goal ("more than 34 percent") in the FY 1995 Performance Agreement.

\section{Small Business Statistics in Visual Aids Prepared for the Former Secretary}

We identified a visual aid (briefing chart) that was prepared for a presentation by the former Secretary to the Congressional Black Caucus on July 12, 1995, that contained incorrect information. Although the title of the chart indicated the dollar amounts on 
the chart represented amounts for women and minority businesses for FY 1992 and FY 1994, the dollar amounts actually represented the total dollar amount for small business prime contracts for those years.

We identified four additional charts that were prepared for briefings on the Department's small business program that contained incorrect information. Three of the four additional charts compared the actual total dollar amount of small business prime contracts for FY 1992 with the FY 1994 goal. The goal, however, was labeled as "DELIVERED." Two of the three charts were prepared for briefings by the former Secretary, while one chart was prepared for a briefing by the Director, ED. With one exception, we could not determine if the charts were used in presentations or, if so, how the information on the charts was characterized. For the one chart that we were able to determine was used by the former Secretary, she verbally characterized the information on the chart correctly. The remaining chart compared percentages of DOE's minority business investments for the years FY 1992 through FY 1995. This chart used a percentage for FY 1995 that was computed on a different basis than the previous years.

\section{BACKGROUND}

The Office of Small and Disadvantaged Business Utilization (OSDBU) is one of several offices within ED. According to the OSDBU Mission Statement, OSDBU has "responsibility within the Department for policy, plans and oversight of . . . the Small Business Act, as amended and Executive Orders ... relating to preference programs for small businesses, disadvantaged businesses, labor surplus area concerns and women-owned businesses." OSDBU's Function Statement further states that OSDBU, "Coordinates and prepares the Department's goals for assigned programs, recommends Directorial approval of such goals and subsequent to Directorial approval, negotiates, establishes and reports on goals for the assigned programs with the cognizant Federal agencies."

The Small Business Act, as amended, requires the head of each Federal agency, after consultation with SBA, to establish goals for the award of contracts to small business concerns and to small business concerns owned and controlled by socially and economically disadvantaged individuals. Within DOE, OSDBU is responsible for the negotiation, establishment, coordination, and reporting of these goals.

Terms that are important to the subject of this report are defined in Appendix A. 


\section{RESULTS OF INSPECTION}

The Office of Inspector General received allegations regarding the development and reporting of the Department's small business contracting statistics. Specifically, it was alleged that ED did not issue a required annual report to Congress on the Department's small business program since 1992. It was also alleged that the Department's FY 1995 Performance Agreement with the President incorrectly communicated that the Department intended to increase small business contracting from 25 percent in FY 1994 to more than 34 percent in FY 1995. Further, it was alleged that ED officials may have provided incorrect information for use in Secretarial presentations on the Department's small business program.

\section{A. Annual Report to Congress on the Small Business Program}

The Department of Energy Act of 1978 - Civilian Applications - Public Law 95-238, Title II $\S 204$, February 25,1978 , as amended by Public Law 96-470, Title II, $\$ 203$ (f), October 19,1980 , states that:

"(b) The Secretary of Energy shall submit annually to the appropriate committees of the House of Representatives and the Senate a full report on the actions taken in carrying out subsection (a) during the preceding year, including the extent to which small business concerns are participating in the programs involved and in projects and activities of various types and sizes within each such program, and indicating the steps currently taken to assure such participation in the future."

We found that the Department was not in compliance with the requirement of the Department of Energy Act of 1978--Civilian Applications, as amended by Public Law $96-470$, to provide an annual report within the required time period to Congress on the Department's small business program.

We determined that, with the exception of the FY 1988 report, for at least 10 years prior to 1993, the Department had submitted to Congress, on an annual basis, a report on the Department's small business program. However, we learned that the Department's FY 1993 report on the small business program was not submitted to Congress until August 1995. Also, on September 30,1997, we were advised by a senior ED official that a small business program report to Congress combining FY 1994/FY 1995 had not yet been signed by the Secretary.

Senior ED officials we interviewed said they knew that the annual reports to Congress on the Department's small business program for FY 1994 and FY 1995 had not been submitted to Congress. When we asked the senior ED official responsible for preparing the report why the Department had not submitted annual reports for FY 1994 and FY 1995, the senior ED official said that field organizations did not respond on a timely basis to a "request for information call," which the ED official said was the major 
cause of delays in getting the FY 1994 report written. Regarding the FY 1995 report, the official said that the report had been delayed for several reasons: reorganizations within the Department, both at Headquarters and in the field; changing missions within the Department; office realignments; and the slowness of receiving information from the field. The official also said that much of the information provided by the field was not accurate, which caused delays because of the need to go back to the field organizations for accurate information.

The senior ED official made the decision to combine the FY 1994 and FY 1995 annual reports to Congress. He said his decision was based on the Department previously combining annual reports for FY 1994 and FY 1995 for a different subject into one report. This report, the "Annual Performance Report," reported the Department's progress toward filling some of the Nation's most important energy related needs. This combined report, the FY 1994 \& FY 1995 Annual Performance Report, had been signed by the former Secretary and sent to the President.

We concluded that ED did not take appropriate action to ensure the required reports on the Department's small business program were submitted on a timely basis.

In commenting on a draft of this report, the Director, ED, stated, "In principle, we agree with the draft Report's finding that the Department is not in compliance with the requirements of the Department of Energy Act of 1978 to provide an annual report to Congress on the Department's small business program." In further commenting on the draft report, the Director stated:

"However, it is important to emphasize that the time period is administratively determined by the affected program office. There is no statutorily [sic] set date by Congress or the Department . . . Based on the records from the Office of the Executive Secretariat's Action Coordination Congressional Reports Tracking System [ACCRTS], the actual dates submitted . . clearly show that the Small Business Reports were not submitted on an annual basis as required by Congress but rather were submitted at various times of the following year to Congress."

\section{Notification to Secretary}

ES established ACCRTS to track reports to the President, Congress, and other Federal agencies, and to track Federal Register Notices and projects of interest to the Office of the Secretary. The ACCRTS guidance stated that: "When a requirement will not meet an administrative due date, the Secretary should be notified by an Information Memorandum."

We found that, although senior ED officials did not make the required notification to the Secretary that the Department's annual small business reports to Congress had not yet been submitted, ED officials had notified ES that the reports were late. 
According to a member of the ES staff, ED had not notified the Secretary by an Information Memorandum that the annual small business reports to Congress had not yet been submitted and would be late. Senior ED officials said they knew the annual small business reports to Congress were late. However, they said they were not aware that the Secretary was to be notified when a report to Congress was going to be late, nor could they recall if there was a requirement to prepare an Information Memorandum to the Secretary concerning the late reports.

In comments to a draft of our report, the Director, ED, said that ES had been notified through the ES Congressional Reports Coordination Tracking System that the reports were late. In view of the Director's comment, ES should evaluate its guidance regarding the process for notifying the Secretary of late reports by an Information Memorandum to determine whether such a requirement is necessary. If it is determined that an Information Memorandum should continue to be required, ES should ascertain whether this requirement is being followed by the Department, and take appropriate action if the requirement is not being followed.

\section{Accuracy of Statistics}

We learned that the Office of Procurement and Assistance Management (Procurement) was concerned with the accuracy of statistics in the combined FY 1994/FY 1995 small business program report being prepared by ED for submission to Congress.

According to a senior ED official, submission of the combined FY 1994/FY 1995 small business program report to Congress had been delayed, in part, because Procurement officials found that the numbers in the reports provided by the field did not match the numbers that they (Procurement) had generated.

In a March 10,1997, memorandum to the Director, ED, Subject: "COMMENTS BY THE OFFICE OF PROCUREMENT AND ASSISTANCE MANAGEMENT ON DRAFT SMALL BUSINESS REPORT FOR FISCAL YEARS 1994 AND 1995," the Deputy Assistant Secretary for Procurement and Assistance Management identified numerous statistical errors that were found in the draft report. The Deputy Assistant Secretary stated that: "We support that the Acting Secretary not sign the report. Since the report is 2 years overdue for FY 1994 and 1 one [sic] year overdue for FY 1995, perhaps someone other than the Secretary of Energy should sign the report."

In comments to a draft of this report, the Deputy Assistant Secretary for Procurement and Assistance Management said that his Office objected to the combined FY 1994/FY 1995 report to Congress "because of the ways in which the data were arrayed and the mathematical errors in the report, not because of a mismatch in data."

Because of the inaccuracies identified by the Office of Procurement and Assistance Management with the statistical data in the combined draft FY 1994/FY 1995 annual report, we believe that internal controls within ED regarding the development and 
reporting of small business contracting statistical data should be strengthened to ensure the accuracy of data provided in reports to Congress and other Government agencies.

In commenting on a draft of this report, the Director, ED, stated that: "With respect to the draft Report's discussion on the accuracy and documentation of the Department's small business contracting statistics, we are also concerned and have been working with the Office of Procurement and Assistance Management to implement appropriate solutions."

\section{B. FY 1995 Performance Agreement with the President}

We found that, although the Department's FY 1995 small business contracting goal had been revised to 18.4 percent and resubmitted to SBA, ED officials did not attempt to change the FY 1995 small business contracting goal ("more than 34 percent") in the FY 1995 Performance Agreement with the President.

The Department is required, on an annual basis, to submit small business contracting goals and prior year achievements to SBA. Public Law 85-536 (the Small Business Act), as amended by Section 221 of Public Law 95-507, requires the head of each Federal agency, after consultation with SBA, to establish goals for participation by small business concerns and by small business concerns owned and controlled by socially and economically disadvantaged individuals, in procurement contracts of the agency. It also requires the head of each Federal agency, at the end of each fiscal year, to report to SBA the extent of participation by small business concerns and small business concerns owned and controlled by socially and economically disadvantaged individuals, in procurement contracts of the agency.

The number for the small business contracting goal submitted by the Department to SBA for FY 1995 was 34.5 percent. The Director, ED, said that the number submitted to SBA was also included in the Department's FY 1995 Performance Agreement submitted to the President. In the FY 1995 Performance Agreement, the former Secretary committed the Department to "IMPROVING ACCESS FOR SMALL BUSINESSES." According to the Performance Agreement, success would be measured by increasing small business contracting from 25 percent in FY 1994 to more than 34 percent by the end of FY 1995. About the time that the President signed the Department's FY 1995 Performance Agreement, the Department was notified by SBA that the numbers for the Department's FY 1994 small business contracting achievements and FY 1995 small business contracting goals would have to be revised. According to SBA, unlike previous years, the Department's small business contracting numbers for FY 1994 achievements and FY 1995 goals did not include Management and Operating (M\&O) contractor "salaries and expenses." Although the Department subsequently revised the number for the FY 1995 small business contracting goal to 18.4 percent and submitted the revised number to SBA, ED officials did not attempt to 
change the FY 1995 small business contracting goal ("more than 34 percent") in the FY 1995 Performance Agreement with the President.

A chronological discussion of selected events that resulted in the former Secretary and the President signing the Department's FY 1995 Performance Agreement is in Appendix B.

The Director, ED, said that the failure to change the number of 34 percent in the FY 1995 Performance Agreement for the Department's FY 1995 small business prime contracting goal, which had been initially provided to SBA, to 18.4 percent was apparently an oversight by ED. She said that she is not aware of a mechanism to make changes to the Performance Agreement. She also said that, at some point, she told then Secretary O'Leary that "we aren't going to make this," referring to the FY 1995 small business contracting goal of more than 34 percent that was in the FY 1995 Performance Agreement. She said that she could not recall what the former Secretary had said in response.

The "Term of Agreement" in the FY 1995 Performance Agreement stated that: "This agreement will remain in effect until modified. It is expected that it will be updated at least annually to reflect significant changes in budget, policy, personnel, or other factors that may affect the accomplishment of objectives."

A senior policy analyst in the Office of Policy and International Affairs told us that "there is a mechanism to make changes to the performance agreement; however, it has never been exercised." The policy analyst also said that ED could have submitted changes to the performance measures that were in the FY 1995 Performance Agreement, but the changes, after going through the process, would not have occurred until the first or second quarter of FY 1996.

We concluded that although ED officials learned that the small business contracting goal in the FY 1995 Performance Agreement with the President was no longer correct, ED officials did not notify the Office of Policy and International Affairs that the Performance Agreement should be changed accordingly.

In commenting on a draft of this report, the Director, ED, stated that: "We do not agree with the initial draft Report's finding that ED did not take appropriate action to ensure the FY 1995 Performance Agreement was changed to include the revised number for the FY 1995 small business contracting goal." The Director, ED, further stated that: "We do not believe there would have been time to change the goal language in the Performance Agreement and, more importantly, we do not believe it was necessary."

In commenting on a draft of this report the Acting Director, Office of Strategic Planning, Budget and Program Evaluation, Office of Policy and International Affairs, stated that: "Although the Agreement for FY 1995 was not formally revised, a mechanism that was used by other offices was to address any necessary changes to commitments in their 
status reports. An example was the discussion of the impact of the Congressional budget rescission on our ability to add the planned 25,000 alternative fuel vehicles to Federal and local fleets."

The comments by the Acting Director indicate that a mechanism was available and was used by other offices to address changes to their commitments in the FY 1995 Performance Agreement with the President. ED, however, did not utilize this mechanism. Although the Director, ED, stated that "at the end of the year, an agency reports to the President on their success in meeting the goals," we reviewed the Department's FY 1994 \& 1995 Annual Performance Report, which was closely linked to the Department's FY 1995 Performance Agreement, and found that it did not include a discussion of the success by the Department in meeting the small business goals.

\section{Calculation of Small Business Goals and Achievements}

According to the Director, ED, a "goaling team" was established comprised of representatives from Headquarters and field organizations to develop the Department's FY 1995 small business contracting goals. She said that instead of Headquarters dictating the goals to the field, it was felt that having field representatives participate in the goaling process would enable them to "buy into" achieving the goals that were established. She said that the goaling team developed an approach for establishing the Department's total procurement baseline. Under this approach, M\&O contractor salaries and expenses were not included in the total procurement baseline. Subsequently, the Department established its FY 1995 small business prime contracting goal of 34.5 percent, which excluded $M \& O$ contractor salaries and expenses. On October 18, 1994, the Department submitted its FY 1995 procurement goals to SBA, which included the number of 34.5 percent for the small business prime contracting goal. The Department was notified by SBA in November 1994, that DOE's FY 1995 procurement goals were accepted.

On May 10, 1995, the Department provided SBA the Department's FY 1994 small business achievements. The Department reported the number for its FY 1994 small business prime contracting achievements as 35.4 percent. The number for the FY 1994 small business prime contracting achievements was calculated using a total procurement baseline that excluded $M \& O$ contractor salaries and expenses. However, SBA had not authorized ED to use the new baseline when calculating the Department's FY 1994 small business prime contracting achievements. This was because the Department had included the $M \& O$ contractor salaries and expenses when previously calculating the FY 1994 small business prime contracting goals.

The Director, ED, stated in her comments on a draft of this report that: "In 1994, when the goal was established at $25 \%$, we were initially unaware that the contracting baseline included monies for M\&O employees' salaries and benefits." 
Our inspection disclosed, however, that the Department had included monies for M\&O employees' salaries and benefits in the contracting baseline in previous year reports to SBA.

In a July 10,1995, letter to the Director, ED, the Deputy Administrator, SBA, notified the Department that SBA would not accept the Department's FY 1994 achievement report. According to the Deputy Administrator's letter, the Department's FY 1994 achievements excluded M\&O salaries and expenses from the FY 1994 procurement baseline and, therefore, were unacceptable. The Deputy Administrator's letter also stated that other agencies had contractual arrangements "similar" to DOE's relationship with the M\&O contractors. Therefore, SBA could not allow all agencies in similar situations to exclude M\&O contractor salaries and expenses from the goaling baseline. As a result, the Deputy Administrator requested that the Department resubmit "1994 achievements and 1995 goals using the total DOE procurement baseline, including salaries and expenses for the M\&O contractors ...."

Subsequently, in August 1995, the Department provided SBA its revised numbers for "1994 achievements and 1995 goals using a baseline that included salaries and expenses for the M\&O contractors." The Department reported its FY 1994 small business prime contracting achievement as 19.5 percent and its FY 1995 small business prime contracting goal as 18.4 percent.

The following table (see Table 1, page 12) is provided to assist in understanding the origin of the numbers (percentages) initially provided by the Department to SBA for its FY 1994 small business prime contracting achievement and FY 1995 small business prime contracting goal, as well as the origin for the revised numbers subsequently provided to SBA. 


\section{TABLE 1}

\section{Summary of Data on DOE Small Business \\ Contracting Goals and Achievements \\ For FY 1994 \& FY 1995 \\ (\$in 000s)}

\begin{tabular}{|c|c|c|c|c|}
\hline & PROPOSED PROCUREMENT GOALS & & FY 94 & FY 95 \\
\hline Row A & Est. Total \$ Value of Prime Contracts (Incl M\&O expenses) & $\$$ & $18,000,000$ & $16,480,000$ \\
\hline Row B & Small Business Prime Contract $\$$ (Goal) & $\$$ & $4,500,000$ & $3,029,100$ \\
\hline Row C & Resulting \% (Goal) & & $25 \%$ & $18.4 \%$ \\
\hline Row D & Est. Total \$ Value of Prime Contracts (w/o M\&O expenses) & & N/A & $8,780,000$ \\
\hline Row E & Resulting \% (Goal) & & & $34.5 \%$ \\
\hline & & & & \\
\hline & RFPORTED ACHIFVFMFNTS & & FY 94 & FY 95 \\
\hline & & & & \\
\hline Row F & Actual Total \$ Value of Prime Contracts (Incl M\&O expenses) & $\$$ & $17,104,716$ & $\$ 16,375,427.00$ \\
\hline Row G & Small Business Prime Contract \$ (Actual) & $\$$ & $3,328,780$ & $3,304,434.00$ \\
\hline Row H & Resulting \% (Actual) & & $19.5 \%$ & $20.2 \%$ \\
\hline Row I & Actual Total $\$$ Value of Prime Contracts (w/o M\&O expenses) & $\$$ & $9,404,716$ & N/A \\
\hline Row J & Resulting \% (Actual) & & $35.4 \%$ & N/A \\
\hline
\end{tabular}

\section{FY 1994 Goal/Achievements}

As illustrated in Table 1, the Department's estimated total dollar value of prime contracts for FY 1994, including M\&O contractor salaries and expenses, was $\$ 18.0$ billion (Row $A$ ). The Department's goal was to award $\$ 4.5$ billion in small business prime contracts (Row B). This resulted in a number of 25 percent for the Department's FY 1994 small business prime contracting goal (Row C), which was reported to SBA.

The actual total value of prime contracts for FY 1994, including M\&O contractor salaries and expenses, was $\$ 17.1$ billion (Row F). In FY 1994, the Department awarded $\$ 3.3$ billion in small business prime contracts (Row $G$ ). This resulted in a number of 19.5 percent for the Department's FY 1994 small business prime contracting achievement (Row $\mathrm{H})$.

However, the number initially reported to SBA for the Department's FY 1994 small business prime contracting achievement was 35.4 percent (Row J). This number 
was calculated using $\$ 9.4$ billion as the total dollar value of prime contracts awarded in FY 1994 (Row I). This total dollar value excluded M\&O contractor salaries and expenses.

\section{FY 1995 Goal/Achievements}

As illustrated in Table 1, the Department's estimated total dollar value of prime contracts for FY 1995, excluding M\&O contractor salaries and expenses, was about $\$ 8.8$ billion (Row $D$ ). The Department's goal was to award about $\$ 3.0$ billion in small business prime contracts (Row B). This resulted in a number for the Department's FY 1995 small business prime contracting goal of 34.5 percent (Row E), which was initially reported to SBA. This number was used as a basis for the FY 1995 small business contracting goal ("more than 34 percent") included in the Department's FY 1995 Performance Agreement.

The Department's estimated total dollar value of prime contracts for FY 1995, including M\&O contractor salaries and expenses, was about $\$ 16.5$ billion (Row A). The Department's goal was to award about $\$ 3.0$ billion in small business prime contracts (Row B). This would have resulted in a number for the Department's FY 1995 small business prime contracting goal of 18.4 percent. This revised number for the Department's FY 1995 small business prime contracting goal was subsequently submitted to SBA at their request. However, ED officials did not notify the Office of Policy and International Affairs that the FY 1995 small business contracting goal ("more than 34 percent") in the FY 1995 Performance Agreement should be changed.

The Department's actual total value of prime contracts for FY 1995, including M\&O contractor salaries and expenses, was about $\$ 16.4$ billion (Row F). In FY 1995, the Department awarded $\$ 3.3$ billion in small business prime contracts (Row $G$ ). This resulted in a number for the Department's FY 1995 small business prime contracting achievement of 20.2 percent (Row H).

\section{Small Business Statistics in Visual Aids Prepared for the Former Secretary}

We received allegations regarding possible incorrect information on visual aids prepared for presentations by the former Secretary and the Director, ED, on the Department's small business program. The following is a brief discussion of five charts that we identified that contained incorrect information.

We identified a visual aid (briefing chart) that was prepared for a presentation by the former Secretary to the Congressional Black Caucus on July 12,1995, that contained incorrect information (see Chart One, page 16). Although the title of the chart indicated the dollar amounts on the chart represented amounts for women and minority businesses for "Bush" (FY 1992) and "Clinton" (FY 1994), the dollar amounts actually represented the total dollar amount for small business prime contracts for those years. 
We identified four additional charts that were prepared for briefings on the Department's small business program that contained incorrect information. Based on the dollar amounts represented by the charts, three of the four additional charts compared the actual total dollar amount of small business prime contracts for FY 1992 with the FY 1994 goal. The goal, however, was labeled as "DELIVERED." Two of the three charts were prepared for briefings by the former Secretary, while one chart was prepared for a briefing by the Director, ED. With one exception, the chart for the Diversity Conference, July 27-29, 1994, we could not determine if the charts were used in presentations or, if so, how the information on the charts was characterized. For the one chart that we were able to determine was used by the former Secretary, she verbally characterized the information on the chart correctly. The remaining chart compared percentages of DOE's minority business investments for the years FY 1992 through FY 1995. This chart used a percentage for FY 1995 that was computed on a different basis than the previous years (see Chart Two, page 18).

\section{Comparison of FY 1992 Actual With FY 1994 Goal}

It was alleged that charts prepared for use by the former Secretary and the Director, ED, compared the FY 1992 actual total dollar amount of the Department's small business prime contracts with the Department's FY 1994 goal and that the charts indicated the goal amount had been delivered.

We identified four charts that contained bars that represented the Department's actual total dollar amount of small business prime contracts for FY 1992 (about $\$ 3$ billion) and the goal for FY 1994 (about $\$ 4.5$ billion). Although the dollar amounts represented by the bars did not change, the banners, headers, and labels on the charts had been changed to designate different small business categories. Also, on three of the charts, the bar representing the dollar amount for the FY 1994 goal was labeled "DELIVERED." This resulted in charts that contained incorrect information, either because the charts incorrectly characterized the Department's goal as being delivered, or because the title of the chart indicated the chart represented a subset of the small business program, even though the dollar amounts represented by the chart were for the total program. Table 2 (see page 15) shows a summary analysis of the charts that compare the FY 1992 actual total dollar amount of the Department's small business prime contracts with the Department's FY 1994 small business contracting goal. 
TABLE 2

\section{ANALYSIS OF THE CHARTS THAT COMPARE}

FY 1992 ACTUAL DATA TO THE FY 1994 GOALS

\section{Date Of \\ Planned \\ Presentation}

$7 / 12 / 95$

$7 / 27 / 94$

ज゙

\section{Was FY 1994 Actual \# Known \\ To DOE?} Presenter $\underline{\text { Audience }}$

S-1

Congressional Black Caucus

S-1

DOE Diversity

Conference

Small, Women \&

Minority Businesses

$\begin{array}{lll}4 / 18 / 95 & \text { S-1 } & \begin{array}{l}\text { White House } \\ \text { Conference on } \\ \text { Small Business }\end{array}\end{array}$

Increased Opportunity for Small Business

4/17/95

ED
Director
Richland Small
Business Diversity
Small, Women \& Conference

\section{Was Goal \\ Bar Labeled \\ "DELIVERED"?}

\section{Chart Correctly \\ Characterized \\ In Talk?}

Undetermined

(Not Yet

Reported

to SBA)

Undetermined
(Not Yet
Reported
to SBA)
Unknown

Yes

Unknown

Yes

Yes

No

Yes

Unknown

Yes

* The data actually presented in the charts were the dollar amount for the Department's FY 1992 actual total small business prime contracts (which included women and minority businesses) and the dollar amount for the Department's FY 1994 goal for small business prime contracts. 
Chart One, which was prepared for a briefing by the former Secretary to the Congressional Black Caucus on July 12, 1995, is an example of a chart that contains incorrect information.

\section{Chart One: SETTING A NEW COURSE - WOMEN \& MINORITY BUSINESSES}

\section{SETTING A NEW COURSE \\ WOMEN \& MINORITY BUSINESSES}

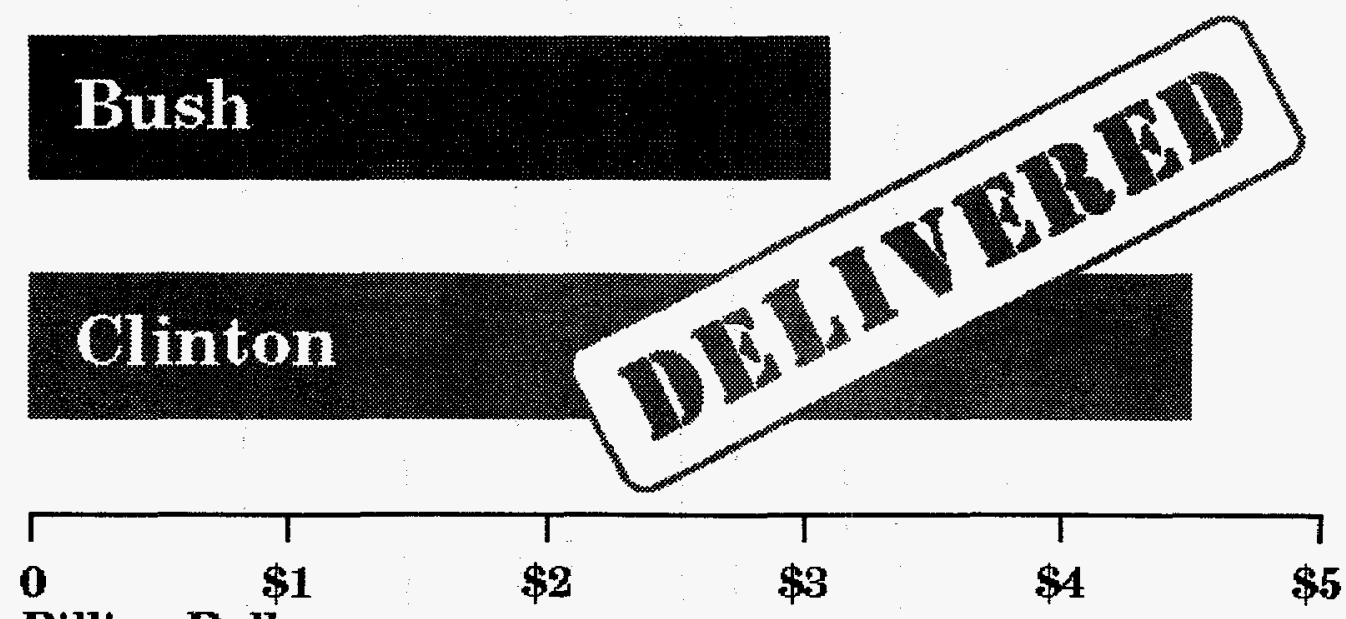

Billion Dollars

Source: DOE Procurement

We determined that the data on the chart relates to the Department's small business prime contract dollar amounts (both the actual amount for FY 1992 and the goal for FY 1994), even though the title indicates that the chart contains data regarding the Department's totals for "WOMEN \& MINORITY BUSINESSES." We found that the actual amounts spent by the Department for women and minority contracts were known for FY 1992 and FY 1994 at the time of the presentation and differed significantly from the statistics presented on the chart. For example, according to the chart, the amount for "WOMEN \& MINORITY BUSINESSES" for FY 1992 was about $\$ 3.1$ billion, while the actual amount as reported by the Department to SBA was $\$ 1.017$ billion. Also, according to the chart, the amount for "WOMEN \& MINORITY BUSINESSES" for FY 1994 was about $\$ 4.5$ billion, while the actual amount as reported by the Department to SBA on May 10, 1995 , was $\$ 1.239$ billion. 
We were unable to determine whether the former Secretary used this chart in her presentation to the Congressional Black Caucus on July 12,1995, or, if it was used, how the information on the chart was characterized. However, we believe the use of the Department's small business prime contract dollar amounts on the chart, both the actual amount for FY 1992 and the goal for FY 1994, to represent the amounts for Women and Minority Businesses (which were known at the time of the presentation), and the label of "DELIVERED" on the "Clinton" bar, make the chart incorrect.

We identified three similar charts that compared the FY 1992 actual total dollar amount of small business prime contracts with the FY 1994 goal, which made the information on the charts incorrect. One chart, titled "DIVERSITY DELIVERED," was prepared for a presentation by the former Secretary to a Diversity Conference in Washington, DC, on July $27-29,1994$. Another chart, titled "ENERGIZING SMALL BUSINESS INCREASED OPPORTUNITY FOR SMALL BUSINESS," was prepared for a presentation by the former Secretary on April 18, 1995, to the White House Conference on Small Business. A third chart, titled "THE ECONOMICS OF DIVERSITY-DOE'S PAST SUCCESSES," was prepared for a presentation by the Director, ED, for the Richland Small Business Diversity Conference, on April 17, 1995.

With one exception, the chart for the Diversity Conference, July 27-29, 1994, we could not determine if the charts were used in presentations or, if so, how the information on the charts was characterized. For the one chart that we were able to determine was used by the former Secretary, she verbally characterized the information on the chart correctly.

\section{Comparison of Percentages Computed on Different Bases}

We identified a chart that compared percentages of DOE's minority business investments for the years FY 1992 through FY 1995, which was also incorrect. This chart, Chart Two, used a percentage for FY 1995 that had been computed on a different basis than the previous years. It was alleged that the percentage increases on the chart were incorrect because the FY 1995 numbers included minority subcontracting data and the other years did not include this data. 


\section{DTVDRSIY - TIE BUSINESS OF RUSINESS \\ THE DOE INVESTMENT}

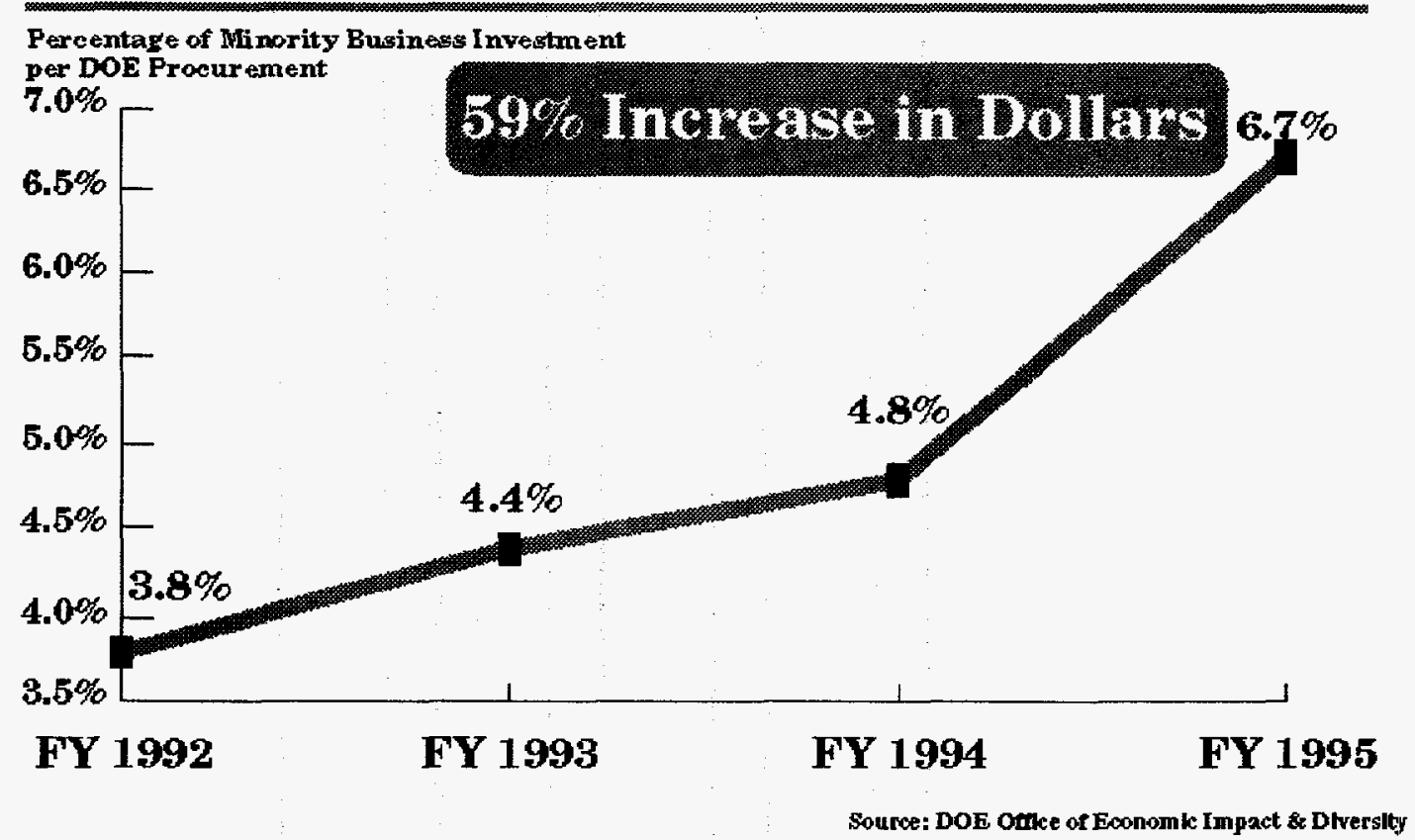

A copy of this chart was in the former Secretary's briefing books for a presentation to the National Coalition of Minority Businesses on April 3, 1996. The chart was also possibly used for a presentation to the Minority Business Community on September 26. 1996.

We were told that the number of 6.7 percent on the chart for the percentage of minority business investment in FY 1995 was calculated using minority subcontracting data, which was not included in the calculation of the percentages for the previous years. According to a Procurement analyst, the Department did not start keeping minority subcontracting data until FY 1995 and the percentage figure for FY 1995 appeared to have been calculated by including minority subcontracting dollars.

According to a knowledgeable member of the ED staff, if the FY 1995 percentage figure was calculated on the same basis as the previous years, e.g., without the minority subcontracting dollars, the percentage figure for FY 1995 would be 6.0 percent, not 6.7 percent as shown on the chart. We were also told that the resultant increase from FY 1992 to FY 1995 would be 42 percent, not a 59 percent increase as shown on the chart. 
We were unable to determine, with certainty, if the former Secretary used the chart in her presentations and, if so, how she characterized the information on the chart. However, we believe the use of data for FY 1995 that was not calculated on the same basis as the data for the previous years makes the chart incorrect.

\section{Source of Chart Statistics}

We found that, in general, there was no back-up material to support the statistical data depicted by the visual aids discussed above, and we could not identify anyone who was willing to take responsibility for the data found on the visual aids. We concluded that internal controls should be strengthened to ensure the accuracy of small business contracting statistics prepared by staff for use by the Secretary and other senior officials.

We attempted to determine who requested the charts containing the small business contracting statistics and the process that led to the preparation of the charts. We were told by a Department visual information officer that he could not recall specifically who requested each chart or how each chart was prepared. He said, however, that he would attend meetings, which were usually chaired by the former Chief of Staff and attended by program officials knowledgeable of the presentation topic, speech writers, members of the former Secretary's staff, and others. He said that sometimes the former Secretary would also attend. He said that during these meetings, he would be asked to prepare a chart on a specific topic and those present would provide information to be put on the chart. He said that, for charts containing small business procurement statistics, the information would sometimes be provided by Procurement officials, while other times the information would be provided by ED officials. He said that when he asked who he should identify as the source of the information on the chart, he would be told to use either the Office of Procurement or ED.

We believe that the source of the small business contracting statistics used in the preparation of visual aids for use by the Secretary and other senior officials, as well as how the statistics were developed, should be documented. If such documentation were available, it would provide an additional internal control to ensure the accuracy of the information used on the visual aids.

In comments to a draft of this report, the Director, ED, stated that:

"We do not agree with the initial draft Report's finding that the charts or visual aids prepared for the former Secretary contained potentially misleading or incorrect information. As the Report indicates, except for one chart, the Inspector General's office could not determine whether the charts or visual aids were actually used or not. For the one visual aid that the Inspector General's office could determine was used by the former Secretary, the former Secretary characterized the information correctly in her presentation. The former Secretary and the ED 
Director consistently used the correct characterization when discussing the Department's small, minority and women-owned business participation with the Department."

As discussed above, our inspection identified five charts prepared for briefings on the Department's small business program that contained incorrect information. Several of these charts were in briefing books prepared for presentations by the former Secretary. The presence of these charts in the briefing books creates the potential for the charts, if used, to provide an inaccurate depiction of the Department's small business contracting statistics. Therefore, we believe that steps should be taken to strengthen internal controls regarding the development of small business contracting statistics and visual aids for use in presentations by the Secretary and other senior officials.

\section{RECOMMENDATIONS}

We recommend that the Director, Office of Economic Impact and Diversity:

1. Ensure that required annual reports to Congress on the Department's small business program are submitted on a timely basis.

Management Comments. The Director, ED, in commenting on a draft of this Report concurred in part with this recommendation, stating that: "In the future, we: will be more prudent in ensuring that ED reports are submitted on a more timely basis. We will also institute a better tracking system for these types of Reports."

We believe the actions by the Director, ED, when implemented, will be responsive. Therefore, this recommendation should remain open until the tracking system identified by the Director is fully implemented.

2. Coordinate with the Office of Procurement and Assistance Management to determine the desirability of identifying a single office responsible for developing and releasing small business statistical information.

Management Comments. The Director, ED, concurred with this recommendation.

In comments to a draft of this report, the Deputy Assistant Secretary for Procurement and Assistance Management, stated that:

". . . the Director, Office of Economic Impact and Diversity and I have completed coordination on Recommendation 2 as follows: .. . The responsibility for collecting, developing, and approving the release of the small business statistical information will be assigned to the Office of Procurement and Assistance Management. The assignment of functions will be formalized in a 
memorandum from the Deputy Secretary and Chief Operating Office to all parties concerned."

We believe that the actions described by the Deputy Assistant Secretary, when implemented, will be responsive to our recommendation. Therefore, until this memorandum is issued this recommendation should remain open.

3. Ensure that information submitted for the Secretary's Performance Agreement with the President is accurate and, if the information is changed, take appropriate action to ensure that changes are reported to the appropriate office so that the Performance Agreement can be revised, if needed.

Management Comments. The Director ED concurred with this recommendation.

The Director, Office of Strategic Planning, Budget and Program Evaluation, Office of Policy and International Affairs, in commenting on a draft of this report stated that, "When the Secretary's FY 1998 Performance Agreement with the President is signed, we plan to ensure program offices are aware of the mechanism to revise it."

We believe that the assignment to the Office of Procurement and Assistance Management, Office of Management Systems (Competition Advocate) (HR-53), of the responsibility for the Department's small business statistical information, as discussed in management's response to recommendation number 2 , should satisfy the need to ensure the accuracy of the small business information submitted for incorporation into the Secretary's Performance Agreement with the President. However, until such time that HR-53 issues policies/procedures implementing their new responsibilities, this recommendation should remain open.

4. Take appropriate action to strengthen internal controls to ensure the accuracy of small business contracting statistical information and visual aids prepared for use by the Secretary and other senior officials.

Management Comments. The Director, ED, concurred with this recommendation.

We believe that the assignment to the Office of Procurement and Assistance Management of the responsibility for collecting, developing, and approving the release of the small business statistical information as discussed in management's response to recommendation number 2 , when implemented, will be responsive to this recommendation. Therefore, until the reassignment of the above responsibility is completed, this recommendation should remain open.

5. Take appropriate action to ensure that the source of the small business contracting statistics used in the preparation of visual aids for use by the 
Secretary and other senior officials, as well as how the statistics were developed, is appropriately documented.

Management Comments. The Director, ED, concurred with this recommendation, and stated that: "With respect to . . the accuracy and documentation of the Department's small business contracting statistics, we are also concerned and have been working with the Office of Procurement and Assistance Management to implement appropriate solutions."

We believe that the assignment to the Office of Procurement and Assistance Management of the responsibility for collecting, developing, and approving the release of the small business statistical information as discussed in management's response to recommendation number 2 , will be responsive to this recommendation. Therefore, until the reassignment of the above responsibility is completed this recommendation should remain open.

We also recommend that the Director, Office of Strategic Planning, Budget and Program Evaluation, Office of Policy and International Affairs:

6. Ensure that DOE program offices are aware of the mechanism to revise information previously submitted in the Secretary's Performance Agreement with the President.

Management Comments. The Director, Office of Strategic Planning, Budget and Program Evaluation, Office of Policy and International Affairs, concurred with this recommendation, and stated that, "When the Secretary's FY 1998 Performance Agreement with the President is signed, we plan to ensure program offices are aware of the mechanism to revise it."

We believe the actions described by the Director, is responsive to our recommendation. Therefore, this recommendation can be closed.

Further, we recommend that the Director, Office of the Executive Secretariat, Office of Human Resources and Administration:

7. Evaluate its guidance in the ACCRTS regarding the process for notifying the Secretary of late reports by an Information Memorandum to determine whether such a requirement is necessary. If it is determined that an Information Memorandum should continue to be required, ascertain whether this requirement is being followed by the Department, and take appropriate action if the requirement is not being followed.

Management Comments. The Director, Office of the Executive Secretariat, concurred with this recommendation and stated that: 
"The Office of the Executive Secretariat (ES) has reviewed its procedures dealing with late reports to Congress. ES believes that its current procedures, which call for the Program Secretarial Officer (PSO) to prepare letters to notify Congress when a report which has [a] due date established by statute or prepare an Information Memorandum to the Office of the Secretary when the due date is established by the program office, are sound management practices.

"ES provides a bi-weekly reminder of the program office's responsibility when it sends out notice to the program office to update their overdue or coming due reporting requirements. . . . ES has directed in the bi-weekly reminder that it is the program offices' responsibility to follow through with notification concerning overdue reports, rather than that of ES."

We believe the Director's actions are responsive to our recommendation. Therefore, this recommendation can be closed. 


\section{Definitions of Important Terms}

The terms defined below are important to the subject of this report.

Small Business - a concern, including its affiliates, that is independently owned and operated, not dominant in the field of operation in which it is bidding on government contracts, and qualified as a small business under the criteria and size standards in Title 13, Code of Federal Regulations, Part 121.

Small Disadvantaged Business - a small business that is at least 51 percent unconditionally owned by one or more individuals who are both socially and economically disadvantaged, or a public owned business that has at least 51 percent of its stock unconditionally owned by one or more socially and economically disadvantaged individuals and that has its management and daily business controlled by one or more such individuals.

(a) Socially disadvantaged individuals means individuals who have been subjected to racial or ethnic prejudice or cultural bias because of their identity as a member of a group without regard to their qualities as individuals.

(b) Economically disadvantaged individuals means socially disadvantaged individuals whose ability to compete in the free enterprise system is impaired due to diminished opportunities to obtain capital and credit as compared to others in the same line of business who are not socially disadvantaged. Individuals who certify that they are members of named groups (Black Americans, Hispanic Americans, Native Americans, Asian-Pacific Americans, Subcontinent-Asian Americans) are to be considered socially and economically disadvantaged.

Women-Owned Small Business - a small business concern:

(a) Which is at least 51 percent owned by one or more women; or, in the case of any publicly owned business, at least 51 percent of the stock of which is owned by one or more women; and

(b) Whose management and daily business operations are controlled by one or more women. 


\section{Development of Small Business Prime Contracting Goal for FY 1995 Performance Agreement}

The following is a chronological discussion of selected events that resulted in the former Secretary and the President signing the Department's FY 1995 Performance Agreement. The Performance Agreement contained an FY 1995 small business prime contracting goal (more than 34 percent) for the Department that differed from the number for the Department's FY 1995 small business contracting goal that was finally provided by the Department to SBA (18.4 percent).

On October 18, 1994, the Department submitted it's FY 1995 procurement goals to SBA. The FY 1995 goals were developed using a baseline consisting of the total dollar value of prime contracts, excluding $M \& O$ salaries and expenses. Using this baseline, the number for the Department's FY 1995 small business prime contracting goal was computed as 34.5 percent.

On October 28, 1994, the Office of Policy and International Affairs received a facsimile from a senior ED official, which identified the Department's small business prime contracting goals for FY 1994 as 25 percent and for FY 1995 as 34.5 percent. A senior policy analyst told us that a contractor employee used this information to prepare the commitment in the Department's FY 1995 Performance Agreement with the President, regarding "IMPROVING ACCESS FOR SMALL BUSINESSES."

In a November 21, 1994, letter to Secretary O'Leary, the Administrator, SBA, accepted the number of 34.5 percent for the Department's FY 1995 small business prime contracting goal.

In a February 6, 1995, letter to the Director, ED, the Deputy Administrator, SBA, stated:

"As we agreed, DOE has a unique situation regarding contracts with private sector firms for the management and operation (M\&O) of its facilities. Inclusion of salaries and benefits paid to the employee's [sic] of these M\&O contractors in the baseline amount used to calculate procurement goals does not give a true picture of the procurement opportunities available to the small business community from DOE. As a result, this year we accepted DOE's goals with the amount paid by M\&O contractors for salaries and benefits excluded from the baseline.

"I believe that the agreement we reached will benefit both DOE and the small business community through the development of goals that are based on the actual procurement dollars available for contracting opportunities." 
In mid-June 1995, the proposed FY 1995 Performance Agreement with the President was signed by the Department's Secretarial Officers and Directors.

On June 22, 1995, then Secretary O'Leary signed the FY 1995 Performance Agreement.

In a July 10,1995, letter to the Director, ED, the Deputy Administrator, SBA, informed the Department that although SBA agreed to allow DOE to exclude salaries and expenses for employees of $M \& O$ contractors from the procurement baseline for goaling purposes in FY 1995, goals for FY 1994 had been submitted based on inclusion of the M\&O salaries and expenses. The Deputy Administrator stated that: "As a result, we could not approve your request to exclude these costs from the fiscal year 1994 baseline. To do so would distort results governmentwide." The Deputy Administrator also stated that:

"In May we received the DOE achievement report for fiscal year 1994. Results were presented excluding $M \& O$ salaries and expenses from the procurement baseline and are therefore unacceptable. In addition, upon further review and discussions with Congress, it has become apparent that many Federal agencies have contractual arrangements similar to DOE's relationship with the M\&O contractors. It would not be in the interest of small business, however, to exclude procurement dollars from the goaling baseline in all such cases. Since we cannot offer this agreement to all agencies in similar situations, it is not appropriate to allow DOE to exclude these dollars. In view of the foregoing, our letter of February 6, 1995, must be rescinded. Please resubmit 1994 achievements and 1995 goals using the total DOE procurement baseline, including salaries and expenses for the M\&O contractors, by July $21,1995 . "$

On July 14,1995 , the Office of Policy and International Affairs was notified by the National Performance Review that the President had signed the Department's FY 1995 Performance Agreement.

In an August 18, 1995, letter to the Deputy Administrator, SBA, the Director, ED, provided SBA the Department's revised FY 1994 small business prime contracting achievements and revised FY 1995 small business prime contracting goals. The revised achievements and goals were developed using a baseline that included M\&O contractor salaries and expenses.

We were told by senior ED officials that the number for the Department's FY 1995 small business prime contracting goal in the FY 1995 Performance Agreement with the President was the number that had been initially reported by the Department to SBA. 
IG Report No. INS-O-98-02

\section{CUSTOMER RESPONSE FORM}

The Office of Inspector General has a continuing interest in improving the usefulness of its products. We wish to make our reports as responsive as possible to our customers' requirements, and therefore ask that you consider sharing your thoughts with us. On the back of this form, you may suggest improvements to enhance the effectiveness of future reports. Please include answers to the following questions if they are applicable to you:

1. What additional background information about the selection, scheduling, scope, or procedures of the audit or inspection would have been helpful to the reader in understanding this report?

2. What additional information related to findings and recommendations could have been included in this report to assist management in implementing corrective actions?

3. What format, stylistic, or organizational changes might have made this report's overall message more clear to the reader?

4. What additional actions could the Office of Inspector General have taken on the issues discussed in this report which would have been helpful?

Please include your name and telephone number so that we may contact you should we have any questions about your comments.

Name

Date

Telephone

Organization

When you have completed this form, you may fax it to the Office of Inspector General at (202) 586-0948, or you may mail it to:

Office of Inspector General (IG-1)

Department of Energy

Washington, D.C. 20585

\section{ATTN: Customer Relations}

If you wish to discuss this report or your comments with a staff member of the Office of Inspector General, please contact Wilma Slaughter at (202) 586-1924. 
The Office of Inspector General wants to make the distribution of its reports as customer friendly and cost effective as possible. Therefore, this report will be available electronically through the Internet at the following alternative address:

Department of Energy Human Resources and Administration Home Page http://www.hr.doe.gov/ig

Your comments would be appreciated and can be provided on the Customer Response Form attached to the report.

This report can be obtained from the

U.S. Department of Energy

Office of Scientific and Technical Information

P.O. Box 62

Oak Ridge, Tennessee 37831 